Arch. Vet. Science 3(1):83-86, 1998

Printed in Brazil

\title{
REVERSIBLE CARDIAC ARREST INDUCED BY STARTLING STIMULI IN THE ANTARCTIC FISH Notothenia neglecta*
}

\section{KATSUMASA HOSHINO ${ }^{1}$; PEDRO HELIO LUCCHIARI ${ }^{2}$; METRY BACILA ${ }^{3}$}

${ }^{1}$ Departamento Ciências Biológicas, Faculdade de Ciências, Universidade Estadual Paulista (Unesp), Bauru, S. Paulo, Brasil; ${ }^{2}$ Departamento de Medicina, Pontifícia Universidade Católica do Paraná, Curitiba, Pr, Brasil.

${ }^{3}$ Laboratório de Piscicultura, Setor de Ciências Agrarias, Universidade Federal do Paraná, Paraná, Brasil

\begin{abstract}
Startling stimuli induce temporary inhibition of heart beats in many animals. Since such property, named reversible cardiac arrest, has not been systematically studied in fishes, the present work investigated its occurrence in an Antarctic fish that evolved independently from other teleost groups. Heart rate changes in response to different stimuli were monitored by conventional electrocardiographic recording in 15 Notothenia neglecta (400-700 grams), maintained in an experimental chamber with aerated sea water and controlled temperature. Sudden vibration of the chamber, observer approximation and other alerting stimuli evoked cardiac arrest sometimes for one or more beats, but the most common response was only a short delay of the beat after the stimulus. Increase in temperature up to $11^{\circ} \mathrm{C}$ raised heart rate but did not abolish the response. Moderate hypoxia facilitated cardiac arrest. Pronounced cardiac inhibition with some isolated beats was observed when the animals were handled or when the water of the chamber was removed. Atropine $(1 \mathrm{mg} / \mathrm{kg})$ administration blocked the cardiac arrest induced by such procedures. It is concluded that reversible cardiac arrest is probably a common property of many fishes and developed before the adaptation to the Antarctic environment.
\end{abstract}

Key Words: Cardiac arrest; Antarctic fish; Notothenia neglecta.

RESUMO - Estímulos de alarme induzem inibição temporária dos batimentos cardíacos em muitos animais. Como essa proprieade, denominada parada (arrest) cardíaca reversível não vem sendo estudada sistematicamente em peixes, os presente trabalho investigou a sua ocorrência em peixes antárticos que evoluíram independentemente de outros grupos de teleósteos. Alterações do ritmo cardíaco em resposta a diferentes estímulos foram monitoradas por registro eletrocardiográfico em 15 espécimes de Notothenia neglecta (400-700 g) mantidas em uma câmara experimental com água do mar aerada e temperatura controlada. Vibrações repentinas da câmara, a aproximação do observador e outros estímulos de alerta provocavam no animal paradas cardíacas algumas vezes por um ou mais batimentos, mas a resposta mais comum era somente de uma parada curta do batimento cardíaco após estímulo. Aumento da temperatura até $11^{\circ} \mathrm{C}$ eleva o ritmo (rate) cardíaco sem abolir a resposta contudo. Hipóxia moderada facilita a parada cardíaca. Inibição cardíaca pronunciada com algum batimento isolado foi observada quando os animais eram manuseados ou quando a água da câmara era removida. Administração de atropina $(1 \mathrm{mg} / \mathrm{kg})$ bloqueia a parada cardíaca induzida por tais procedimentos. Conclui-se, então, que a parada cardíaca reversível é provavelmente uma propriedade comum de muitos peixes que se desenvolveu antes da sua adaptação ao ambiente antártico.

Palavras-Chave: Parada cardíaca; Peixes Antárticos; Nototheia neglecta.

\section{Introduction}

Notothenioid fishes from Antarctic seas seem to be originated by geographical isolation during the early Tertiary Period and evolved independently from other teleostei groups (DeWITT, 1971; JOHNSON et al., 1983). Along such evolution they developed some unusual physiological adaptations such as conspicuous low hematocrit levels (EVERSON and RALPH, 1968), presence of antifreezing glycoproteins (DeVRIES et al., 1970), and

\footnotetext{
*Research carried out at the Brazilian Antarctic Station "Comandante Ferraz" during the VI and VII Brazilian Antarctic Expedition. Logistic and financial support CIRM/PROANTARCNPq.
}

efficient enzymatic activity at low temperatures (JOHNSON and WALESBY, 1977). These animals constitute, therefore, a reliable source of information about the adaptation to extreme cold environment and about the phylogenetic development of some physiological mechanisms through comparative studies.

It is well known that the low hematocrit level or the absence of hemoglobin in Antarctic fishes are adaptative characteristics to solve the problem of increase in blood viscosity in cold environments. These adaptative processes are compensated by other cardio-circulatory mechanisms, as a greater heart size of the ice-fish, that grants a high plasmatic flux to satisfy the oxygen and other nutrients requirements. 
Teleost heart rate is modulated by the cholinergic inhibitory activity of the vagus nerve like in many other vertebrates and this innervation is responsible for the reversible cardiac arrest (RCA). RCA is defined as a neurogenic interruption of heart beats in response to startling stimuli and described to occur in some mammals, arthropods and mollusks. In birds and fishes it has not been systematically investigated (CUADRAS, 1981). The present study was carried out to investigate if RCA occurs in the Notothenia neglecta since interruption or lowering in plasmatic flow promoted by cardiac activity arrest seems incompatible with their adaptative requirements.

\section{Methods}

Fifteen Notothenia neglecta without sex determination, weighing 400 to 700 grams, were used. They were caught by net at 40-50 m depth in the Admiralty Bay (King George Island) and kept in current sea water aquarium with controlled temperature $\left(0^{\circ} \mathrm{C}\right)$. Two to seven days were allowed for habituation before experimentation.

Two electrodes made from stainless steel hypodermic needles (12 to $18 \mathrm{~mm}$ length and 0.8 mm external diameter) connected to a flexible and isolated cable were implanted and fixed by surgical suture. One of them was inserted in the pericardium and the other subcutaneously in the abdominal region, both approximately at the midline of the ventral surface of the fishes. The animals were immediately put in the observation chamber (LUCCHIARI et al., 1984) and five or ten hours for adaptation allowed. The observation chamber was made with translucent plexiglass consisting of an internal animal compartment filled with sea water and an external compartment filled with glycerol solution maintained at desired levels of temperature. The animal compartment was aerated by an external air-pump and the air temperature cooled in a copper coil tubing inside the external compartment of the chamber before bubbling into the sea water. The chamber was kept in a Faraday cage and the cables of both electrodes were connected to a conventional electrocardiograph recorder (Coretron II). The laboratory fluorescent light was always kept on, except when the light effect on cardiac activity was tested. Noise level in the laboratory was kept low.

Observations were started at temperatures ranging from 0 to $1^{\circ} \mathrm{C}$, with a control recording and subsequently different kinds of startling stimuli presented at irregular intervals. The stimuli tested were: sudden noise (hand claps); sudden mechanical vibratory stimuli (knocking the cage); observer approximation; white paper card movement close to the animal and flashlight. Each kind of stimulus was tested five folds at least presented at random intervals and sequences. The laboratory was darkened for 10 - 15 minutes before the test made with a flashlight provided by a photographic camera. The effect of increase in temperature $\left(1^{\circ} \mathrm{C} /\right.$ hour $)$ on the RCA was tested, using mechanical vibration of the cage as startling stimuli.

A minimum of 60 minutes was allowed for recovering after the test with temperature change, and the RCA was tested under hypoxia at $0^{\circ} \mathrm{C}$. For this, air-pump was turned off and mechanical vibration of the cage made at random intervals of time. Hypoxia was suspended when evident bradycardia was observed. After a new recovery period, atropine $(1.0 \mathrm{mg} / \mathrm{kg})$ was injected into the pericardic cavity, and 15 minutes later, RCA induced by sudden vibration of the cage tested.

The water of the experimental chamber was renewed frequently during observations since mucous secretion and feces were common. For this, dirt sea water was gently drained through a sewer existing at the chamber's floor and substituted. As this procedure was repeatedly made, electrocardiographic recordings were made when animals were exposed to air.

\section{Results}

Control electrocardiographic (ECG) recordings made in the $N$. neglecta showed always conspicuous QRS complex, but only sometimes its associated $\mathrm{P}$ and $\mathrm{T}$ waves were clearly depicted. In many occasions, mainly in hypoxic conditions, ECG tracings were overrode by slow sinusoidal waves corresponding to opercular movements and $\mathrm{T}$ waves with progressive higher amplitudes recorded. QRS complex amplitude ranged from 0.4 to $1.2 \mathrm{mV}$ and the baseline heart rate at 0 to $1.0^{\circ} \mathrm{C}$ gave a mean value of $31+6$ beats/minute.

Sudden vibration of the cage showed to be the most efficacious stimulus to evoke the suspension of one or more heart beats or a short delay in the heart beat following the stimulus presentation. The latency of this RCA was extremely short and seemed instantaneous to the visual inspection. Under regular pre-stimulus cardiac frequency was resumed after one or two beats without changes in QRS wave amplitude. In all tested animals, sudden noise, observers approximation or white card movement near the observation chamber, induced only a short increase in the time interval between two consecutive heart beats. Except for vibration of the cage, this response to many kinds of stimuli vanished when they were repeated more than three folds. Flashlight did not change the regular heart rate. Fig. 1A shows the most common response to the startling stimuli in the $N$. neglecta. Very small 
body movements, including a rapid fin beat were sometimes observed in response to the startling stimuli.

Heart rate increased progressively with the rise in temperature, reaching $68-72$ beats/minute at $8^{\circ}$ C. Sudden vibration of the cage continued to induce the RCA (Fig. 1B). An increase in the amplitude of opercular movements without significant change in the heart rate was observed 20-30 minutes after the suspension of the air bubbling into the animal chamber. RCA induced by sudden vibration of the chamber was difficult to be observed under hypoxic condition since bradycardia per se increased the interval between consecutive heart beats.

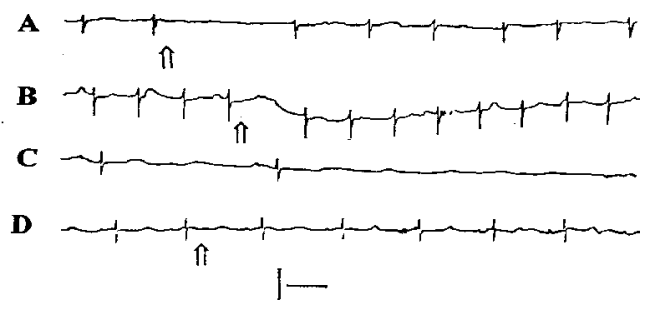

Fig 1. Reversible cardiac arrest in the Antarctic fish Notothenia neglecta. Instantaneous (phasic) heart beat delay or missing induced by sudden mechanical vibration (arrows) of the experimental chamber at $0^{\circ}(\mathrm{A})$ and $8^{\circ} \mathrm{C}$ (B). and a prolonged (tonic) heart beat suspension is induced by the exposition of the animal to atmospheric air (C). Atropine $(1 \mathrm{mg} / \mathrm{kg})$ inhibits the reversible cardiac arrest (D). Calibration: $1 \mathrm{mV}$ and 1 second.

Prolonged tonic RCAs were observed when the fish were manipulated or restrained by the observers in order to check the position of the electrodes or their cables. Only few isolated ECG waves were observed to occur interspersed in 1020 seconds periods of cardiac activity inhibition. Cardiac activity was also observed to be suspended when the water of the observation chamber was completely drained and animals were exposed to air (Fig. 1C). Like during manipulation, only sporadic ECG waves occurred.

Atropine $(1 \mathrm{mg} / \mathrm{kg})$ injection into the pericardic cavity blocked both phasic an tonic RCA within five to fifteen minutes without affecting the general behavior of the animals.

\section{Discussion}

The results obtained indicate that the Antarctic fish $N$. neglecta interrupts or delays regular heart beats in response to startling stimuli. The absence of such RCA in response to flashlight and the fast habituation to other stimuli, except sudden vibration of the chamber, seems to be associated to their presence and significance in the natural habitat of the animal. Being a benthic fish, living at 40 or more meters of depth, mechanical information proceeding from the surrouding water seems to be the most important kind of environmental stimulus and, consequently, its sudden occurrence being more startling than others. $N$. neglecta revealed to display a rapid and short lasting phasic RCA in response to startling stimuli and a long lasting tonic type induced by restraint or when out of water. Heart beat inhibition induced by mechanical stimulation of the gills was observed in the earlier study made by McWILLIAM (1985) in the eel and SHELTON and RANDALL (1962) observed bradycardia mediated by the vagus nerve activity in the tench when the water flow over the gills was stopped. The prolonged cardiac inhibition in $N$. neglecta when exposed to air or when handled (animal head was always secured) can be explained as induced by a reflex involving branchial receptors and vagus inhibitory activation. The phasic RCA of the $N$. neglecta is similar to those described to occur in other teleosts (LABAT, 1966; DEGHAID, 1986; IDE, 1997), and seems also to be mediated by the vagal cholinergic inhibitory activity since atropine injection blocked it.

If RCA does have or not a general physiological meaning is yet unknown (CUADRAS, 1981). One of the most suitable suggestion about it is that RCA could represent concealment from predators or prey that might be able to detect the regular electrical or pressure gradients associated with cardiac or branchial pumping as proposed by McMAHON e WILKENS (1972). Although $N$. neglecta ambush preys (DANIELS,1982), such adaptative function of RCA can not be claimed for since exteroceptive startling stimuli induced only RCA with extreme short duration.

The occurrence of RCA in the Antarctic fish has an unquestionable heuristic value to unveil its functional role. As it occurs in a fish that requires a higher and constant blood flow in order to compensate low hematocrit level, it seems to indicate that RCA plays an important functional role since it supersedes the adaptation needs. On the other hand, RCA occurrence in Notothenioid fish, which evolved independently from other teleostei groups from the early Tertiary Period (DeWITT, 1971), leads to suppose that this cardiac response might have developed before the adaptation to cold Antarctic conditions. Being a more primitive phylogenetic acquisition, RCA can be expected to occur in many other teleosts. RCA in the $N$. neglecta seems to be in accordance with the hypothesis advancing that the RCA in the fish is an antecipatory protective manifestation of the startle reaction that protects the branchial capilaries from the transient raise in blood pressure that the intense and rapid motor contraction of the body for flight promotes (OLIVEIRA and HOSHINO, 1989). The cardiac arrest in response to water removal from the 
observation chamber, however, may be interpreted as a response to the impossibility of branchial ventilation and/or by the lammellar coalescence.

Cardiovascular control mechanisms in fishes are now well established and are the subject of many reviews (e.g. RANDALL, 1968, 1970; LAURENT et al., 1983; FARREL, 1984; BAGSHAW, 1985). Temperature elevation increases heart rate adjusting blood flow to the metabolic demands (PROSSER, 1973), acting directly on cardiac cells excitability (TSUKUDA et al., 1985). Bradycardia in hypoxic condition was observed to be concomitant to blood pressure rise in the trout (HOLETON and RANDALL, 1967) and may apparently involve baroreceptors triggering and vagal mediation. These physiological adjustments were observed also in the $N$. neglecta and it is therefore possible to state that although this fish have evolved independently from other groups they maintained the same basic mechanisms of cardiovascular control. RCA with its protective functional role may be one of these preserved mechanisms.

\section{REFERENCES}

BAGSHAW, R.J. Evolution of cardiovascular baroreceptor control. Biol. Rev. 60:121-162, 1985.

CUADRAS, J. Behavioral determinants of severe cardiac inhibition. Physiological Psychology. 9:384-392, 1981.

DANIELS, R.A. Feeding ecology of some fishes of the Antarctic peninsula. Fishery Bulletin. 80:575-888, 1982.

DEGHAID, F. Paradas cardíacas temporárias da tilapia induzidas pela estimulação ambiental em diferentes temperaturas (Temporary cardiac arrest in the tilápia induced by enviromental stimuli at different temperatures). Monograph. Universidade Estadual Paulista, Botucatu (S.P Brazil), 25p, 1986.

DeWITT, H.H. Coastal and deep-water fishes of the Antarctic. Antarctic Map Folio Series of the American Geographical Society. 15:1-10, 1971

DeVRIES, A.L.; KOMATSU, S.K.; FEENEY, R.E. Chemical and physical properties of freezing pointdepressing glycoproteins from Antarctic fishes. $J$. Biol. Chem. 245:2901-2908, 1970.

EVERSON, I.; RALPH, R. Blood analysis of some Antarctic fish. Br. Antarct. Surv. Bull. 15:59-62, 1968.

FARREL, A.P. A review of cardiac performance in the teleost heart: intrinsic and humoral regulation. Can. J. Zool. 62:523-536, 1984.
HOLETON, G.F.; RANDALL, D.J. Changes in blood pressure in the rainbow trout during hypoxia. J. Exp. Biol. 46:297-305, 1967.

IDE, L.M. Controle tônico e fásico (parada cardíaca reversível) da atividade cardíaca em tilápias-do-Nilo, Oreochromis niloticus. Thesis. Faculdade de Medicina, Universidade de São Paulo, Ribeirão Preto, 1997.

JOHNSON, I.A.; FITCH, N.; ZUMMO, G.; WOOD, R.E.; HARRISON, P.; TOTA, B. Morphometric and ultrastructural features of the hemoglobinless ice-fish Chaenocephalus aceratus. Comp. Biochem. Physiol. 76A:475-480, 1983.

JOHNSON, I.A.; WALESBY, N.J. Molecular mechanisms of temperature adaptation in fish myofibrillar adenosine triphosphatases. J. Comp. Physiol. 119:195-206, 1977.

LABAT, R. Électrocardiologie chez les poissons téléostées: Influence de quelques facteur écologiques. Annales de Limnologie. 2:1-175, 1966.

LAURENT, P.; HOLMGREN, S.; NILSSON, S. Nervous and humoral control of the fish heart: structure and function. Comp. Biochem, Physiol. 76A:525-542, 1983.

LUCCHIARI, P. H.; FEOFILLOFF, E.F.; BOSCARDIM, A.T.; BACILA, M. A technique for the determination of the available oxygen in the living carp. Comp. Biochem. Physiol. 78:675-679, 1984.

McMAHON, B.R.; WILKENS, J.L. Simultaneous apnoea and bradycardia in the lobster Homarus americanus. Can. J. Zool. 50:165-170, 1972.

McWILLIAN, J.A. On the structure and rhythm of the heart in fishes, with special reference to the heart of the eel. Physiol. (London). 6:192-245, 1985.

OLIVEIRA, P.C.; HOSHINO, K. Heart rate in fishes during interspecific interactions. Bol. Fisiol. Anim. 13:49-54, 1989.

PROSSER, C.L. Temperature. In: Comparative Animal Physiology, ed by C.L. Prosser, Philadelphia, Saunders, 165-211, 1973.

RANDALL, D.J. Functional morphology of the heart in fishes. Am. Zool. 8:179-189, 1968.

RANDALL, D.J. The circulatory system. Fish Physiol. 4:132-172, 1970.

SHELTON, G.; RANDALL, D.J. The relationship between heart beat and respiration in teleost fish. Comp. Biochem. Physiol. 7:237-250, 1962.

TSUKUDA, H.; LIU, B.; FUJII, K. Pulsation rate and oxygen consumption of isolated hearts of the goldfish Carassius auratus, acclimated to different temperatures. Comp. Biochem. Physiol. 82A:281-283, 1985. 